\title{
DIETARY SHIFTS AMONG SONGBIRDS FROM A DIFLUBENZURON-TREATED FOREST ${ }^{1}$
}

\author{
Bradley E. Sample, ${ }^{2}$ Robert J. Cooper ${ }^{3}$ And Robert C. Whitmore \\ Division of Forestry, West Virginia University, Morgantown, WV 26506
}

\begin{abstract}
Absiract. Effects of diflubenzuron (a chitin-synthesis inhibiting insecticide) application on diets of forest birds were evaluated in eastern West Virginia in 1986. Nine species of songbirds were collected from May through July from treated and untreated plots. Gut contents from each specimen were removed and 10 arthropod taxa were identified. The percentage biomass comprised by each food taxon and total gut biomass was determined for each specimen. The diets of five species were significantly different between treated and untreated plots. In general, biomass of Lepidoptera larvae was reduced and biomass of other orders (Homoptera, Diptera, Coleoptera, etc.) was greater at treated sites. In addition, two species displayed reduced total gut biomass at treated sites. These data show that while diflubenzuron is not directly toxic to vertebrates, birds are affected indirectly through reduced availability of Lepidoptera larvae. Birds possessed differing capabilities to compensate for these diflubenzuron-induced food reductions. Most birds adjusted by switching prey, while others consumed less food. Resident species experienced less impact than did migrants.
\end{abstract}

Key words: Diflubenzuron; Eastern Wood-Pewee; Black-capped Chickadee; Tufted Titmouse; Blue-gray Gnatcatcher; Red-eyed Vireo; Pine Warbler; Cerulean Warbler; Wormeating Warbler; Scarlet Tanager; diet composition; indirect effects; pesticides.

\section{INTRODUCTION}

Diflubenzuron (common name: Dimilin or 1-[4chlorophenyl]-3-[2,6-diflubenzoyl] urea) is an insecticide widely used to control forest defoliating pests. In the eastern United States, it is applied in midspring to extensive areas of forest to slow the spread and reduce the extent of forest defoliation by gypsy moth (Lymantria dispar $\mathrm{L}$.) larvae. In 1990 , over 269,000 ha of forest were treated with diflubenzuron (US Forest Service 1990).

Diflubenzuron acts by inhibiting the synthesis of chitin, a primary component of the arthropod exoskeleton (Grosscourt and Jongsma 1987). Because mortality occurs when the insect molts, diflubenzuron is most effective against immature or larval insects and is generally not lethal to adult insects (Maas et al. 1981). The acute toxicity of diflubenzuron to birds and mammals is extremely low; the acute oral $\mathrm{LD}_{50}$ for Red-winged Blackbirds (Agelaius phoeniceus) was reported as $3.8 \mathrm{~g} / \mathrm{kg}$ body mass by Maas et al. (1981).

\footnotetext{
${ }^{1}$ Received 8 December 1992. Accepted 8 March 1993.

${ }^{2}$ Present address: Oak Ridge National Laboratory, Environmental Sciences Division, P.O. Box 2008, Oak Ridge, TN 37831-6038.

${ }^{3}$ Present address: Department of Biology, Memphis State University, Memphis, TN 38152.
}

The effects of diflubenzuron are not restricted to populations of target insects. In West Virginia, Martinat et al. (1988) found significant reductions in the populations of non-target, canopydwelling larval Macrolepidoptera and non-lepidopteran mandibulate herbivores following diflubenzuron application. Effects on non-target aquatic insects (Hansen and Garton 1982, Bradt and Williams 1990) and beneficial insects (Granett and Weseloh 1975, Broadbent and Pree 1984) also have been documented.

There is no evidence that diflubenzuron application has direct effects on avian populations (Richmond et al. 1979, DeReede 1982, Stribling and Smith 1987, Cooper et al. 1990). However, because Lepidoptera larvae are a major dietary component for many forest birds (Robinson and Holmes 1982, Cooper 1988, Holmes and Schultz 1988), diflubenzuron application significantly reduces the abundance of Lepidoptera larvae (Martinat et al. 1988), and application occurs at the time of both peak abundance of, and demand for, Lepidoptera larvae (Graber and Graber 1983), birds may be indirectly affected by reductions in their food supply.

Earlier research showed reductions in the percentage abundance of Lepidoptera larvae in the diet of birds from diflubenzuron-treated areas (Cooper et al. 1990). Additionally, male Redeyed Vireos (scientific name in Table 1) spent 
TABLE 1. Results of factorial analyses of variance (ANOVA) of total biomass of gut contents and multiple analyses of variance (MANOVA) of arcsine-transformed percentage biomass of arthropod taxa in the diet of songbirds from diflubenzuron-treated and untreated sites at SCPHFA in 1986. Only orders that accounted for $>2 \%$ of total biomass were included in MANOVA models.

\begin{tabular}{|c|c|c|c|c|c|c|c|c|}
\hline \multirow[b]{2}{*}{ Species } & \multirow[b]{2}{*}{ Source } & \multirow{2}{*}{\multicolumn{3}{|c|}{ ANOVA of gut contents }} & \multicolumn{4}{|c|}{ MANOVA of $\%$ biomass prey taxa } \\
\hline & & & & $\frac{1}{P}$ & $\begin{array}{c}\text { Wilk's } \\
\text { Lambda }\end{array}$ & $F$ & df & $P$ \\
\hline $\begin{array}{l}\text { Eastern Wood-Pewee } \\
\text { (Contopus virens) }\end{array}$ & $\begin{array}{l}\text { Treatment } \\
\text { Month } \\
\text { Treatment*Month }\end{array}$ & $\begin{array}{l}1.70 \\
0.38 \\
0.20\end{array}$ & $\begin{array}{l}1,30 \\
2,30 \\
2,30\end{array}$ & $\begin{array}{l}0.20 \\
0.69 \\
0.81\end{array}$ & $\begin{array}{l}0.78 \\
0.20 \\
0.38\end{array}$ & $\begin{array}{l}0.94 \\
4.18 \\
2.10\end{array}$ & $\begin{array}{r}7,24 \\
14,48 \\
14,48\end{array}$ & $\begin{array}{r}0.49 \\
<0.01 \\
0.03\end{array}$ \\
\hline $\begin{array}{l}\text { Black-capped Chickadee } \\
\text { (Parus atricapillus) }\end{array}$ & $\begin{array}{l}\text { Treatment } \\
\text { Month } \\
\text { Treatment*Month }\end{array}$ & $\begin{array}{l}2.85 \\
1.58 \\
0.47\end{array}$ & $\begin{array}{l}1,18 \\
2,18 \\
2,18\end{array}$ & $\begin{array}{l}0.11 \\
0.23 \\
0.63\end{array}$ & $\begin{array}{l}0.56 \\
0.14 \\
0.68\end{array}$ & $\begin{array}{l}1.69 \\
3.63 \\
0.45\end{array}$ & $\begin{array}{r}6,13 \\
12,26 \\
12,26\end{array}$ & $\begin{array}{r}0.19 \\
<0.01 \\
0.92\end{array}$ \\
\hline $\begin{array}{l}\text { Tufted Titmouse } \\
\text { (Parus bicolor) }\end{array}$ & $\begin{array}{l}\text { Treatment } \\
\text { Month } \\
\text { Treatment*Month }\end{array}$ & $\begin{array}{l}0.06 \\
0.54 \\
1.58\end{array}$ & $\begin{array}{l}1,29 \\
2,29 \\
2,29\end{array}$ & $\begin{array}{l}0.80 \\
0.59 \\
0.22\end{array}$ & $\begin{array}{l}0.60 \\
0.40 \\
0.62\end{array}$ & $\begin{array}{l}2.13 \\
2.05 \\
0.88\end{array}$ & $\begin{array}{r}7,23 \\
14,46 \\
14,46\end{array}$ & $\begin{array}{l}0.08 \\
0.03 \\
0.57\end{array}$ \\
\hline $\begin{array}{l}\text { Blue-gray Gnatcatcher } \\
\text { (Polioptila caerulea) }\end{array}$ & $\begin{array}{l}\text { Treatment } \\
\text { Month } \\
\text { Treatment*Month }\end{array}$ & $\begin{array}{l}1.49 \\
5.66 \\
0.26\end{array}$ & $\begin{array}{l}1,34 \\
2,34 \\
2,34\end{array}$ & $\begin{array}{r}0.23 \\
<0.01 \\
0.77\end{array}$ & $\begin{array}{l}0.54 \\
0.30 \\
0.39\end{array}$ & $\begin{array}{l}2.91 \\
2.79 \\
2.04\end{array}$ & $\begin{array}{r}8,27 \\
16,54 \\
16,54\end{array}$ & $\begin{array}{r}0.02 \\
<0.01 \\
0.03\end{array}$ \\
\hline $\begin{array}{l}\text { Red-eyed Vireo } \\
\quad \text { (Vireo olivaceus) }\end{array}$ & $\begin{array}{l}\text { Treatment } \\
\text { Month } \\
\text { Treatment*Month }\end{array}$ & $\begin{array}{l}0 . .07 \\
0.27 \\
2.25\end{array}$ & $\begin{array}{l}1,36 \\
2,36 \\
2,36\end{array}$ & $\begin{array}{l}0.79 \\
0.76 \\
0.12\end{array}$ & $\begin{array}{l}0.63 \\
0.66 \\
0.65\end{array}$ & $\begin{array}{l}2.59 \\
1.04 \\
1.04\end{array}$ & $\begin{array}{r}7,31 \\
14,62 \\
14,62\end{array}$ & $\begin{array}{l}0.03 \\
0.43 \\
0.42\end{array}$ \\
\hline $\begin{array}{l}\text { Cerulean Warbler } \\
\text { (Dendroica cerulea) }\end{array}$ & $\begin{array}{l}\text { Treatment } \\
\text { Month } \\
\text { Treatment*Month }\end{array}$ & $\begin{array}{l}5.13 \\
4.83 \\
6.24\end{array}$ & $\begin{array}{l}1,10 \\
2,10 \\
2,10\end{array}$ & $\begin{array}{l}0.04 \\
0.03 \\
0.03\end{array}$ & $\begin{array}{l}0.32 \\
0.27 \\
0.59\end{array}$ & $\begin{array}{l}5.53 \\
7.35 \\
1.85\end{array}$ & $\begin{array}{l}3,8 \\
3,8 \\
3,8\end{array}$ & $\begin{array}{l}0.02 \\
0.01 \\
0.21\end{array}$ \\
\hline $\begin{array}{l}\text { Pine Warbler } \\
\text { (Dendroica pinus) }\end{array}$ & $\begin{array}{l}\text { Treatment } \\
\text { Month } \\
\text { Treatment*Month }\end{array}$ & $\begin{array}{l}0.01 \\
0.88 \\
0.12\end{array}$ & $\begin{array}{l}1,18 \\
2,18 \\
2,18\end{array}$ & $\begin{array}{l}0.92 \\
0.43 \\
0.73\end{array}$ & $\begin{array}{l}0.68 \\
0.11 \\
0.62\end{array}$ & $\begin{array}{l}0.63 \\
2.84 \\
0.82\end{array}$ & $\begin{array}{r}8,11 \\
16,22 \\
8,11\end{array}$ & $\begin{array}{l}0.72 \\
0.01 \\
0.59\end{array}$ \\
\hline $\begin{array}{l}\text { Worm-eating Warbler } \\
\text { (Helmitheros vermivorus) }\end{array}$ & $\begin{array}{l}\text { Treatment } \\
\text { Month } \\
\text { Treatment*Month }\end{array}$ & $\begin{array}{l}5.30 \\
0.88 \\
1.01\end{array}$ & $\begin{array}{l}1,11 \\
2,11 \\
2,11\end{array}$ & $\begin{array}{l}0.04 \\
0.44 \\
0.39\end{array}$ & $\begin{array}{l}0.31 \\
0.54 \\
0.12\end{array}$ & $\begin{array}{l}1.59 \\
2.37 \\
1.31\end{array}$ & $\begin{array}{l}7,5 \\
14,10 \\
14,10\end{array}$ & $\begin{array}{l}0.31 \\
0.08 \\
0.35\end{array}$ \\
\hline $\begin{array}{l}\text { Scarlet Tanager } \\
\quad \text { (Piranga olivacea) }\end{array}$ & $\begin{array}{l}\text { Treatment } \\
\text { Month } \\
\text { Treatment*Month }\end{array}$ & $\begin{array}{l}4.70 \\
2.72 \\
0.79\end{array}$ & $\begin{array}{l}1,34 \\
2,34 \\
2,34\end{array}$ & $\begin{array}{l}0.04 \\
0.08 \\
0.46\end{array}$ & $\begin{array}{l}0.36 \\
0.14 \\
0.35\end{array}$ & $\begin{array}{l}7.07 \\
6.52 \\
2.72\end{array}$ & $\begin{array}{r}7,28 \\
14,56 \\
14,56\end{array}$ & $\begin{array}{l}<0.01 \\
<0.01 \\
<0.01\end{array}$ \\
\hline
\end{tabular}

more time foraging and covered larger areas in search of food at diflubenzuron-treated sites than at untreated sites (Cooper et al. 1990).

In this paper, we evaluate the biomass of food consumed by nine insectivorous forest passerines collected at diflubenzuron-treated and untreated sites. The null hypotheses tested are that total biomass of food consumed and the composition of diets (percentage biomass of prey taxa) are not different between birds at treated and untreated sites.

\section{STUDY SITES}

Study sites were located within the 8,000 ha Sleepy Creek Public Hunting and Fishing Area (SCPHFA), approximately $10 \mathrm{~km}$ southeast of Berkeley Springs, West Virginia, in Morgan and Berkeley counties. This area consists of Third Hill and Sleepy Creek mountains, parallel ridges extending from the SSW to the NNE (maximum elevation $658 \mathrm{~m}$ ). The ridges are forested in second-growth oak-hickory, with white (Quercus $a l b a)$, chestnut ( $Q$. prinus), northern red $(Q . r u$ bra), black ( $Q$. velutina), and scarlet oaks $(Q$. coccinea), hickories (Carya spp.), red maple (Acer rubrum), and pitch pine (Pinus rigida) as the dominant tree species. In 1985, this area was along the leading edge of the expanding gypsy moth range; however, no measurable forest defoliation occurred at the time of this study.

\section{METHODS}

A linear series of six $770 \mathrm{~m} \times 770 \mathrm{~m}(59.2 \mathrm{ha})$ plots was established along the west slope of Third Hill Mountain. Treatment status was assigned systematically to even-numbered plots after a random start. This design assured spatial interspersion of treated and untreated plots and 
avoided a pseudoreplicated design that could result from segregated selections (Hurlbert 1984). Plots were separated by at least $150 \mathrm{~m}$ to minimize effects of spray drift. Diflubenzuron was aerially applied as a $25 \%$ wettable powder to treatment plots at a rate of $70.75 \mathrm{~g} / \mathrm{ha}$ on 9 May 1986 as part of the West Virginia Department of Agriculture Gypsy Moth Suppression Program. Spray cards (Barry et al. 1978) placed in buffer areas between plots indicated that no spray reached untreated plots.

Between 06:00 and 13:00 hr from 13 May to $22 \mathrm{July}$, we collected individuals of nine bird species (Eastern Wood-Pewee, Black-capped Chickadee, Tufted Titmouse, Blue-gray Gnatcatcher, Red-eyed Vireo, Pine Warbler, Cerulean Warbler, Worm-eating Warbler, and Scarlet Tanager; scientific names in Table 1) from interiors of treated and untreated plots. The gastrointestinal tract of each bird was extracted and injected with formalin to prevent digestion, then preserved in $75 \%$ ethanol. In the laboratory, gut contents were washed into a petri dish and analyzed under a dissecting microscope. Individual arthropods, usually fragmented, were pieced together until we accounted for all identifiable prey. The number of individual prey items per sample was determined in a manner similar to that described by Anthony and Kunz (1977). For each head capsule, pair of antennae, mandibles or eyes, six legs (or tarsi), or four wings (two for Diptera) encountered, only one prey item was counted. For example, a sample with one head capsule and eight legs was presumed to represent two prey items while a sample with three head capsules and eight legs was presumed to represent three prey items. All prey items were identified to order. Lengths of individual prey items were estimated by comparing characteristic body parts from diet samples to voucher specimens of known size. Biomass of prey items was determined using length-weight regressions (Sample et al. 1993). Total biomass of gut contents and percentage of total biomass each order of prey taxa represented were calculated for each bird.

Univariate factorial analyses of variance were performed on the total gut biomass for each bird species using PROC GLM (SAS Institute 1988). Because birds display seasonal dietary shifts (Cooper 1988) and to determine if diflubenzuron application affected these seasonal shifts, treatment, month (May, June, or July), and the interaction between treatment and month were the independent variables used in the analyses. May generally corresponds to territory establishment, mating, and egg laying, June with incubation and hatching, and July with fledging for most migratory species in our study area.

Multivariate analyses of variance were performed on the arcsine-transformed percentage biomass of each prey order in the diet of each bird species. To reduce the influence of minor prey orders, only those orders accounting for $>2 \%$ of the mean total biomass for each bird species were included in the MANOVA models. Differences were considered significant if $P<0.05$.

Contribution of each prey order to significant multivariate dietary differences was evaluated by correlating canonical scores (eigenvector coefficients multiplied by original variable values) to the original variables. Mean canonical scores were calculated for each level of the effect variable, and the differences in the mean canonical scores were explained as functions of the original variables (Bray and Maxwell 1985).

\section{RESULTS}

Total biomass of gut contents was significantly reduced at treated plots for Worm-eating Warblers and Scarlet Tanagers and greater at treated plots for Cerulean Warblers (Table 1, Fig. 1). In addition, a significant month effect and treatment-by-month interaction were observed for Blue-gray Gnatcatchers and Cerulean Warblers, respectively. No other effects or interactions were significant for any other species.

Four species displayed significant multivariate treatment effects: Blue-gray Gnatcatchers, Redeyed Vireos, Cerulean Warblers, and Scarlet Tanagers (Table 1, Fig. 1). The treatment canonical variable for each species was negatively correlated with the biomass of Lepidoptera larvae consumed and positively correlated with at least one of the following: Araneae, Hemiptera, Homoptera, Coleoptera, adult Lepidoptera, or Diptera (Table 2). For Scarlet Tanagers, the treatment canonical variable also was negatively correlated with the biomass of Orthoptera. Mean treatment canonical variable values for all four species were greater at treated sites (Table 2), indicating reduced consumption of Lepidoptera larvae (and Orthoptera for Scarlet Tanagers) and increased consumption of at least one of the other prey taxa among birds at treated sites.

All species except Red-eyed Vireos and Wormeating Warblers displayed significant multivar- 
TABLE 2. Correlation coefficients for treatment canonical variables and percentage biomass values for prey taxa included in multiple analyses of variance (MANOVA) models. Only bird species with significant treatment effects are presented. *: $P<0.05$. **: $P<0.01$.

\begin{tabular}{lcccc}
\hline \hline \multicolumn{1}{c}{ Order } & $\begin{array}{c}\text { Blue-gray } \\
\text { Gnatcatcher }\end{array}$ & $\begin{array}{c}\text { Red-eyed } \\
\text { Vireo }\end{array}$ & $\begin{array}{c}\text { Cerulean } \\
\text { Warbler }\end{array}$ & $\begin{array}{c}\text { Scarlet } \\
\text { Tanager }\end{array}$ \\
\hline Araneae & 0.23 & 0.12 & & $0.36^{*}$ \\
Orthoptera & & -0.27 & & $-0.71^{* *}$ \\
Hemiptera & -0.11 & $0.66^{* *}$ & & -0.11 \\
Homoptera & 0.21 & 0.03 & $0.83^{* *}$ & $0.38^{* *}$ \\
Coleoptera & -0.06 & 0.02 & $0.50^{*}$ & $-0.51^{* *}$ \\
Lepidoptera (L) & $-0.45^{* *}$ & $-0.42^{* *}$ & $-0.99^{* *}$ & $-0.42^{* *}$ \\
Lepidoptera (P) & & & & \\
Lepidoptera (A) & -0.04 & $0.66^{* *}$ & & \\
Diptera & $0.92^{* *}$ & & & 0.17 \\
Hymenoptera & 0.21 & & & \\
Mean ( \pm SE) Canonical Variable & $1.34 \pm 0.07$ & $0.13 \pm 0.05$ & $-0.34 \pm 0.21$ & $0.31 \pm 0.04$ \\
$\quad$ Treated & $1.07 \pm 0.03$ & $-0.09 \pm 0.03$ & $-1.03 \pm 0.16$ & $-0.07 \pm 0.08$ \\
Untreated & & & & \\
\hline
\end{tabular}

iate seasonal differences in the amounts of the ten prey taxa consumed (Table 1, Fig. 1). While each of the ten prey taxa was significantly correlated with the month canonical variables for at least one bird species, no general pattern was evident.

Multivariate treatment-by-month interactions were observed for Eastern Wood-Pewees, Bluegray Gnatcatchers, and Scarlet Tanagers (Table 1, Fig. 1). Among Eastern Wood-Pewees the interaction was explained by variation in the consumption of Diptera, adult and larval Lepidoptera, Coleoptera, and Homoptera (Fig. 1). Variation in consumption of Diptera, Orthoptera, larval Lepidoptera, Coleoptera, and Homoptera dominated the treatment-by-month interactions for Blue-gray Gnatcatchers and Scarlet Tanagers (Fig. 1).

\section{DISCUSSION}

There has been little research on the sublethal or indirect effects of insecticides on forest birds. Previous efforts focused on either organophosphates (i.e., Milliken 1989, Milliken and Smith 1990) or carbamates (i.e., Hunter et al. 1984, Hunter and Witham 1985), both cholinesteraseinhibiting compounds directly toxic to birds (Smith 1987). In contrast to compounds previously studied, direct toxicity from diflubenzuron is extremely unlikely because the compound acts on a metabolic pathway unique to arthropods and possesses an extremely high vertebrate $L D_{50}$ (Maas et al. 1981). While Lepidoptera larvae are directly affected by diflubenzuron application
(Martinat et al. 1988), the impacts we observed among forest birds are entirely indirect; they result solely from the reduced abundance of a key food resource.

Dietary shifts, where the consumption of Lepidoptera larvae decreased and that of alternate prey increased at diflubenzuron-treated sites, were observed for five of nine bird species. Dietary shifts following diflubenzuron application have also been recorded by DeReede (1982). Following diflubenzuron application, DeReede (1982) observed the percentage of Lepidoptera larvae in the diet of nestling Great Tits (Parus major) decreased while that of Diptera increased.

It is not unusual for insectivorous birds to exhibit dietary shifts in response to changing prey densities in undisturbed systems (Rotenberry 1980, Rosenberg et al. 1982, Cooper 1988, Recher 1989). Most of the species studied here normally shift from a diet dominated by springdefoliating Lepidoptera larvae in the early-mid spring (May) to a more diverse diet in late springearly summer (June-July), in which Homoptera and Coleoptera often dominate (Cooper 1988). This shift is due to a decrease in the availability of larvae as the breeding season progresses and an increase in the availability of other taxa. Although Lepidoptera larvae remained the preferred food, diets of most birds reflect these changes in availability. Even species that usually do not eat many Lepidoptera larvae, such as flycatchers, eat caterpillars when they are available. Apparently, declines in caterpillar abundance caused by diflubenzuron application caused most 

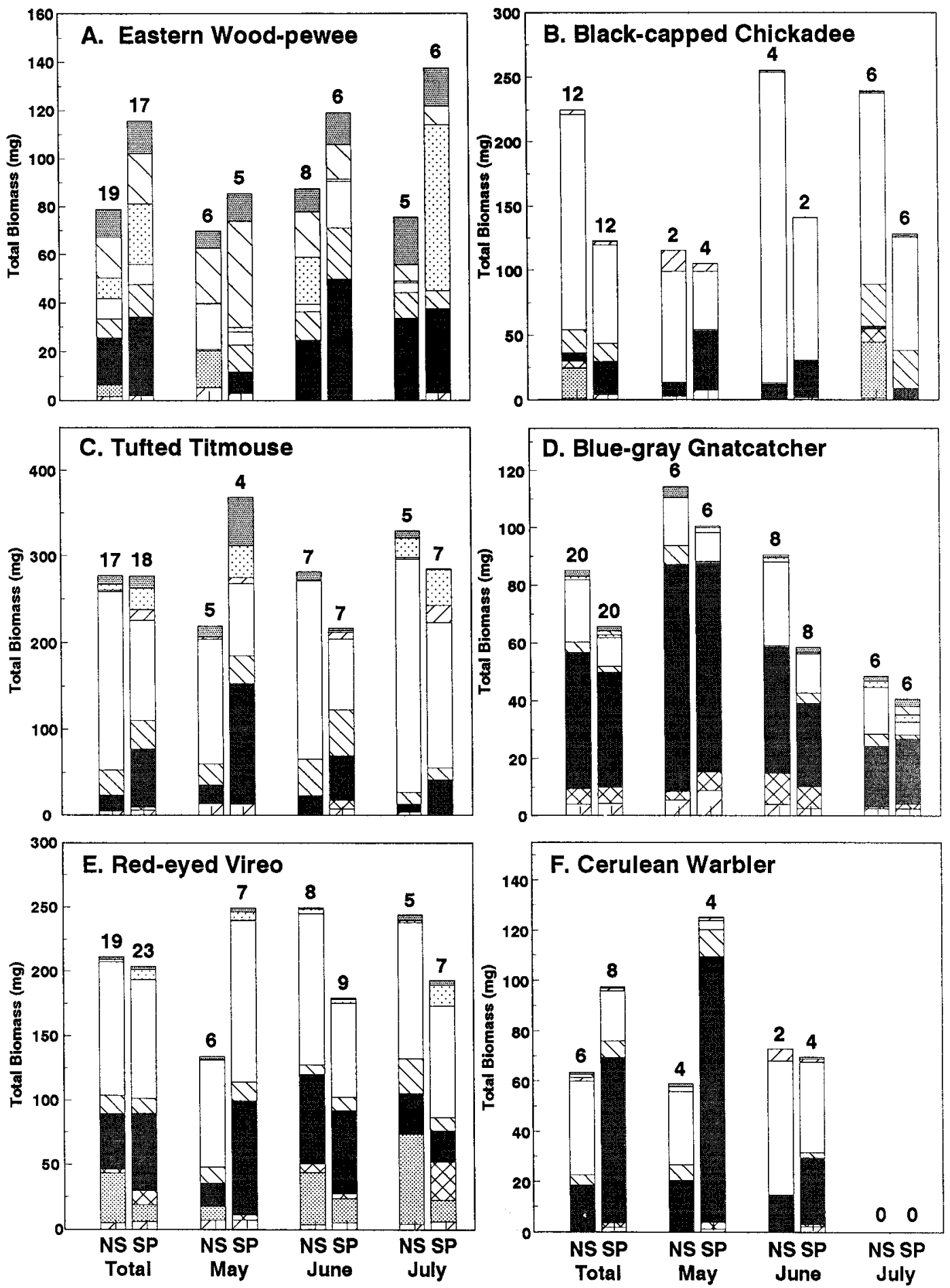

FIGURE 1. Biomass of arthropod taxa in the diet of songbirds from diflubenzuron-treated and untreated sites at SCPHFA from May through July 1986. Bar height represents mean biomass of stomach contents. Segments within bars represent mean biomass per arthropod taxa. Values above bars indicate sample size. 

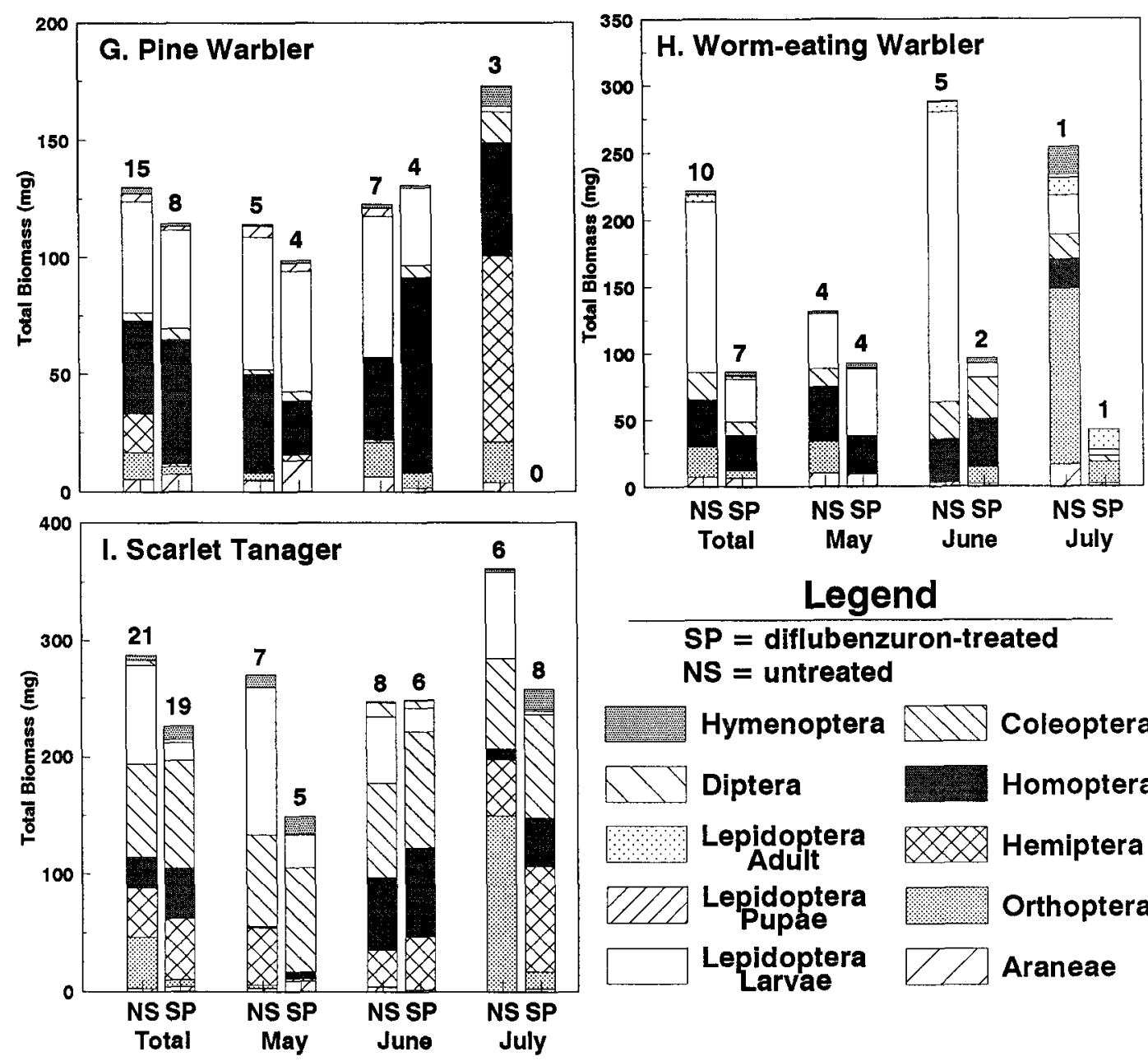

Hymenoptera
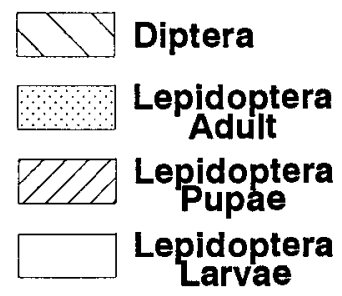

Coleoptera Homoptera Hemiptera Orthoptera Araneae

FIGURE 1. Continued.

birds to switch diets to non-lepidopteran prey in May, earlier than they normally would. Unlike later in the breeding season, however, there may not be adequate alternate prey at that time.

What are the costs of a diet shift? This may be partially determined by comparing the nutritional value of Lepidoptera larvae to other prey types. Lepidoptera larvae have both high fat (Redford and Dorea 1984) and very low chitin content relative to other insect taxa. The cuticle (approximately 60\% chitin [Karasov 1990] accounts for about $4 \%$ of the dry mass of Lepidoptera larvae, whereas about $47 \%$ of the dry mass of orthopterans of comparable size consists of cuticle (Bernays 1986). Because most vertebrates, including birds, are incapable of digesting chitin (Bell 1990), all biomass consumed in the form of chitin is of little nutritional value. Because of their low chitin, high digestibility, and high fat content, Lepidoptera larvae are a higher quality food than most other arthropod prey (Redford and Dorea 1984). As a result of shifting the diet from Lepidoptera larvae to other taxa, birds would have to consume greater amounts of food to get the same nutritional value as they would from an equal amount of Lepidoptera larvae.

To find the greater amounts of food required, birds in treated areas would have to spend more time searching or enlarge the areas within which they search. Increased search activity, enlarged foraging areas, and use of different foraging substrates have all been observed among birds in insecticide-treated areas (Hunter et al. 1984, 
Hunter and Witham 1985, Donahoe 1987, Cooper et al. 1990, Milliken and Smith 1990).

Ultimately, all responses of the birds to reduced abundance of Lepidoptera larvae entail an energetic cost. The energetic costs of a diflubenzuron-induced food reduction was evaluated by considering the fat reserves of birds from treated and untreated sites (Whitmore et al., in press). Those data, collected concurrently with this study, indicated that all species, except Black-capped Chickadees and Tufted Titmice, displayed significantly reduced subcutaneous body fat levels at treated sites. By considering those data along with these diet data, responses of forest birds to the indirect effects of diflubenzuron begin to become evident.

One species, the Worm-eating Warbler, did not adjust to the reduced availability of their preferred food by switching to alternate prey. Although Greenberg (1987) believed that Wormeating Warblers demonstrated some degree of behavioral plasticity, shifting from foraging on insects obtained from live foliage on their breeding grounds to those from dead foliage on their wintering grounds, such plasticity is probably morphologically constrained. To economically switch diets from caterpillars to more active prey requires greater use of flying maneuvers. Both Greenberg (1987) and Cooper (unpubl. data) demonstrated that Worm-eating Warblers rarely use flying maneuvers to capture prey. This species may find it uneconomical to pursue more active prey, even when sedentary prey, like caterpillars, become rare and therefore may be affected by this insecticide treatment.

The next group, consisting of Eastern WoodPewees, Blue-gray Gnatcatchers, Red-eyed Vireos, and Cerulean Warblers, was able to consume sufficient biomass of food by exploiting alternate prey types. However, either because of the reduced quality of food (i.e., higher chitin, lower fat content) or increased energy expended in search of food (larger territories or more time spent foraging), insufficient energy was obtained from the altered diet. Apparently as a result, the fat reserves of these species were reduced.

Scarlet Tanagers were the most strongly affected species. In addition to shifting diet, they consumed less food and displayed reduced fat levels. The strong effect on this species may have resulted from foraging in the upper canopy (Maurer and Whitmore 1981, Sabo and Holmes 1983), the portion of the forest where the greatest impact from aerial spraying would be expected. Also normal, seasonal, diet shifts by Scarlet Tanagers go from Lepidoptera larvae to Coleoptera and Orthoptera (Cooper 1988). Adult Coleoptera generally are not affected by diflubenzuron, and comprised a large portion of the Scarlet Tanager diets in treated areas in this study. Orthoptera, however, are affected by diflubenzuron (Martinat et al. 1988). Thus, two important prey taxa of Scarlet Tanagers (Orthoptera and Lepidoptera larvae) were reduced in abundance, whereas only one was reduced for most other bird species.

There were no dietary differences between treatments for Pine Warblers, and birds at treated and untreated sites consumed the same biomass of prey. However, fat reserves were reduced at treated sites (Whitmore et al., in press). Diets in both treated and untreated areas contained large percentages of caterpillars. Perhaps Pine Warblers expended more energy to locate this relatively rare prey item on treated plots.

The last two species, Black-capped Chickadees and Tufted Titmice, experienced little effect from diflubenzuron application. There are several factors that may contribute to the minimal effect experienced by these species. First, both species forage primarily by gleaning prey from substrates without flying (Robinson and Holmes 1982, Kellner et al. 1990). In contrast, Eastern WoodPewees most frequently hawk prey from midair (Johnston 1971; Cooper, unpubl. data) and the other species employ a variety of flying maneuvers (Bennett 1980; Maurer and Whitmore 1981; Robinson and Holmes 1982; Cooper, unpubl. data). The energetic cost of foraging while perched on a leaf or branch is likely to be much less than that required to forage while in flight.

In addition to less energetic foraging behavior, both Black-capped Chickadees and Tufted Titmice are resident species (DeGraff et al. 1981). Resident chickadees and titmice may not experience the dramatic fluctuations in fat levels experienced by migrating species (Loria and Moore 1990). Even after a harsh winter, they will have had more time to restore depleted fat reserves than migrants. They, therefore, may start the breeding season in better condition (i.e., with greater fat reserves) than the migrants. Also, both species may be more familiar with habitat and locations where food may be available than would the other, migratory species.

Another factor may be that many parids, including Black-capped Chickadees and Tufted 
Titmice, cache food (Sherry 1989). Stored food (seeds and invertebrates) may permit these small birds to access a greater proportion of the available food before being displaced by larger birds. Storing food may also serve to reduce the effects of diflubenzuron-induced food reductions.

A growing body of knowledge indicates that while diflubenzuron is not directly toxic, its application for gypsy moth control indirectly affects birds by reducing food availability. While reproduction in birds may be limited by food availability (Martin 1987), effects on avian reproduction resulting from diflubenzuron application have not yet been documented (Richmond et al. 1979, DeReede 1982, Shearer 1990). However, reproductive effects have been shown for Bacillus thuringiensis $(\mathrm{Bt})$, a gypsy moth control agent that, like diflubenzuron, is lethal primarily to Lepidoptera larvae and has low vertebrate toxicity (DuBois and Lewis 1981). Rodenhouse and Holmes (1992) observed that abundance and biomass of Lepidoptera larvae were reduced following Bt application. They also showed that Black-throated Blue Warblers (Dendroica caerulescens) in treated areas made fewer nesting attempts and nestlings were fed fewer Lepidoptera larvae.

If temperate deciduous forest birds are generally food limited (Holmes et al. 1986), factors such as insecticide application that reduce food availability could be detrimental to their populations. More research is needed to determine if the indirect impacts of diflubenzuron on avian diets translates into effects on reproductive success.

\section{ACKNOWLEDGMENTS}

Funds for this research were provided by Cooperative Agreement No. 42-437 between the USDA Forest Service and West Virginia University. We thank L. Butler, R. L. Smith, and P. Wood for reviewing the manuscript. In addition, we thank our field technicians for assisting in collecting samples. This paper is published with the approval of the Director, West Virginia Agriculture and Forestry Experiment Station as Scientific Article No. 2390. This is contribution No. 14 of the Forest Arthropod Research Team.

\section{LITERATURE CITED}

ANThony, E.L.P., AND T. H. Kunz. 1977. Feeding strategies of the little brown bat, Myotis lucifugus, in southern New Hampshire. Ecology 58:775-786.

BarRY, J. W., R. B. EkBlad, G. P. MARKIN, AND G. C. Trostle. 1978. Methods for sampling and assessing deposits of insecticidal sprays released over forests. USDA For. Serv. Tech. Bull. 1596.
BeLl, G. P. 1990. Birds and mammals on an insect diet: a primer on diet composition analysis in relation to ecological energetics. Stud. Avian Biol. 13:416-422.

BennetT, S. E. 1980. Interspecific competition and the niche of the American Redstart (Setophaga ruticilla) in wintering and breeding communities, p. 319-335. In A. Keast and E. S. Morton [eds.], Migrant birds in the Neotropics: ecology, behavior, distribution, and conservation. Smithson. Inst. Press, Washington DC.

BERNAYS, E. A. 1986. Evolutionary contrasts in insects: nutritional advantages of holometabolous development. Physiol. Entomol. 11:377-382.

Bradt, P. T., AND J. A. Williams. 1990. Response of Hydropsychidae (Insecta: Trichoptera) larvae to diflubenzuron. J. Pa. Acad. Sci. 64:19-22.

Bray, J. H., AND S. E. Maxwell. 1985. Multivariate analysis of variance. Sage University Paper Series. No. 54.

Broadbent, A. B., and D. J. Pree. 1984. Effects of diflubenzuron and BAY SIR 8514 on beneficial insects associated with peach. Eviron. Entomol. 13:133-136.

COOPER, R. J. 1988. Dietary relationships among insectivorous birds of an eastern deciduous forest. Ph.D.diss., West Virginia University, Morgantown, WV.

Cooper, R. J., K. M. Dodge, P. J. Martinat., S. B. DONAHOE, AND R. C. WhITMORE. 1990. Effect of diflubenzuron application on eastern deciduous forest birds. J. Wildl. Mgmt. 54:486-493.

DeGraff, R. M., G. M. Witman, J. W. Lanier, B. J. HiLl, AND J. M. Keniston. 1981. Forest habitat for birds of the northeast. U.S. Forest Service Northeast Forest Experiment Sta.

DeReene, R. H. 1982. A field study on the possible impact of the insecticide diflubenzuron on insectivorous birds. Agro-Ecosystems 7:327-342.

Donahoe, S. B. 1987. The effect of forest defoliation, food abundance, and forest structure on the foraging and territorial behavior of the Red-eyed Vireo (Vireo olivaceous). Unpubl. M.Sc.thesis, West Virginia Univ., Morgantown, WV.

DuBors, N. R., AND F. B. Lewis. 1981. What is $\mathrm{Ba}$ cillus thuringiensis? J. Arboriculture 7:233-240.

Graber, J. W., AND R. R. Graber. 1983. Feeding rates of warblers in spring. Condor 85:139-150.

Granett, J., AND R. M. Weseloh. 1975. Dimilin toxicity to the gypsy moth larval parasitoid, Apanteles melanoscelus. J. Econ. Entomol. 86:577-580.

GreENBERG, R. 1987. Seasonal foraging specialization in the Worm-eating Warbler. Condor 89:158168.

Grosscourt, A. C., And B. Jongsma. 1987. Mode of action and insecticidal properties of diflubenzuron, p. 75-99. In J. E. Wright and A. Retnakaran [eds.], Benzoylphenyl ureas. Plenum, New York.

Hansen, S. R., and R. R. Garton. 1982. The effects of diflubenzuron on a complex laboratory stream community. Arch. Environ. Contam. Toxicol. 11: $1-11$.

Holmes, R. T., AND J. C. SCHultz. 1988. Food availability for forest birds: effects of prey distribution 
and abundance on bird foraging. Can. J. Zool. 66: $720-728$.

Holmes, R. T., T. W. Sherry, and F. W. Sturges. 1986. Bird community dynamics in a temperate deciduous forest: long-term trends at Hubbard Brook. Ecol. Monogr. 56:201-220.

Hunter, M. L., AND J. W. Witham. 1985. Effects of a carbaryl-induced depression of arthropod abundance on the behavior of Parulinae warblers. Can. J. Zool. 63:2612-2616.

Hunter, M. L., J. W. Witham, And H. Dow. 1984. Effects of a carbaryl-induced depression in invertebrate abundance on the growth and behavior of American Black Duck and Mallard ducklings. Can. J. Zool. 62:452-456.

Hurlbert, S. H. 1984. Pseudoreplication and the design of field experiments. Ecol. Monogr. 54:187211.

Johnston, D. W. 1971. Niche relacionships among some deciduous forest flycatchers. Auk 88:796804.

Karasov, W. H. 1990. Digestion in birds: chemical and physiological determinants and ecological implications. Stud. Avian Biol. 13:391-415.

Kellner, C. J., K. G. Smith, N. C. Wilkinson, and D. A. JAMES. 1990. Influence of periodical cicadas on foraging behavior of insectivorous birds in an Ozark forest. Stud. Avian Biol. 13:375-380.

LORIA, D. E., AND F. R. MoOre. 1990. Energy demands of migration on Red-eyed Vireos. Behav. Ecol. 1:24-35.

MaAs, W., R. Van Hes, A. C. Grosscourt, and D. H. DuEl. 1981. Benzoylphenylurea insecticides, p. 423-470. In R. Wegler [ed.], Chemie der Phlanzenshutz und Schladlingsbekampfungsmittel. Band 6. Springer-Verlag, Berlin.

Martin, T. E. 1987. Food as a limit on breeding birds: a life history perspective. Ann. Rev. Ecol. Syst. 18:453-487.

Martinat, P. J., C. C. Coffman, K. M. Dodge, R. J. COOPER, AND R. C. WhitMORE. 1988. Effect of Dimilin $25-W$ on the canopy arthropod community in a central Appalachian forest. J. Econ. Entomol. 81:261-267.

Maurer, B. A., AND R. C. Whitmore. 1981. Foraging of five bird species in two forests with different vegetation structure. Wilson Bull. 93:478490.

Milliken, R. L. 1989. Effects of fenitrothion on the arthropod food of tree-foraging forest birds. Can. J. Zool. 68:2235-2242.

Milliken, R. L., AND J.N.M. Smrth. 1990. Sublethal effects of fenitrothion on forest passerines. J. Appl. Ecol. 27:983-1000.

ReCHER, H. F. 1989. Foraging segregation of Austra- lian warblers (Acanthizidae) in open forest near Sydney, New South Wales. Emu 89:204-215.

Redford, K. H., AND J. G. Dorea. 1984. The nutritional value of invertebrates with emphasis on ants and termites as food for mammals. J. Zool. Lond. 203:385-395.

Richmond, M. L., C. J. Henny, R. L. Floyd, R. W. Mannan, D. M. Finch, and L. R. DeWeese. 1979. Effects of Sevin-4-Oil, Dimilin, and Orthene on forest birds in northeastern Oregon. U.S. For. Serv. Res. Paper PSW-148.

Robinson, S. K., AND R. T. Holmes. 1982. Foraging behavior of forest birds: the relationships among search tactics, diet, and habitat structure. Ecology 63:1918-1931.

Rodenhouse, N. L., AND R. T. Holmes. 1992. Results of experimental and natural food reductions on breeding Black-throated Blue Warblers. Ecology 73:357-372.

RosenberG, K. V., R. D. Ohmart, and B. W. ANDERson. 1982. Community organization of riparian breeding birds: response to an annual resource peak. Auk 99:260-274.

ROTENBERRY, J. T. 1980. Dietary relationships among shrubsteppe passerine birds: competition or opportunism in a variable environment? Ecol. Monogr. 50:93-110.

SABo, S. R., AND R. T. Holmes. 1983. Foraging niches and the structure of forest bird communities in contrasting montane habitats. Condor 85:121-138.

Sample, B. E., R. J. Cooper, R. D. Greer, And R. C. WHITMORE. 1993. Estimation of insect biomass by length and width. Am. Midl. Nat. 129:234240.

SAS InstituTE. 1988. SAS/STAT users guide, Release 6.03. SAS Institute, Inc. Cary, NC.

Shearer, J. A. 1990. Studies of the Acadian Flycatcher (Empidonax virescens): responses to Dimilin treatments and nest site selection. Unpubl. M.Sc.thesis, West Virginia University, Morgantown, WV.

Sherry, D. F. 1989. Food storing in the Paridae. Wilson Bull. 101:289-304.

Smith, G. J. 1987. Pesticide use and toxicology in relation to wildlife: organophosphorus and carbamate compounds. U.S. Fish and Wildlife Service Resource Publ. 170.

Stribling, H. L., AND H. R. SMITH. 1987. Effects of Dimilin on diversity and abundance of forest birds. North. J. Appl. For. 4:37-38

U.S. Forest Service. 1990. Gypsy moth news. 24: 1-9. State and Private Forestry, Forest Pest Management, 370 Reed Rd., Broomall, PA 19008.

Whitmore, R. C., R. J. CoOper, ANd B. E. SAmple. In press. Bird fat reductions in forests treated with Dimilin. Environ. Toxicol. Chem. 